\title{
О ПОПЕРЕЧНОЙ ПЕТРОГЕОХИМИЧЕСКОЙ ЗОНАЛЬНОСТИ МЕЗОЗОЙСКИХ ВУЛКАНИТОВ В РУДНЫХ ПОЛЯХ ЗАБАЙКАЛЬСКОГО СЕГМЕНТА МОНГОЛО-ОХОТСКОГО СКЛАДЧАТОГО ПОЯСА
}

\author{
Абрамов Баир Намжилович, \\ b_abramov@mail.ru \\ Институт природных ресурсов, экологии и криологии СО РАН, \\ Россия, 672014, г. Чита, ул. Недорезова, 16а, а/я 1032.
}

\begin{abstract}
Актуальность работы обусловлена необходимостью изучения закономерностей формирования оруденения в Забайкальском сегменте Монголо-Охотского складчатого пояса.

Цель работы состоит в установлении условий образования, выявлении наличия поперечной геохимической зональности в мезозойской вулканической дуге Забайкальского сегмента Монголо-Охотского складчатого пояса.

Методы. Определение элементного состава пород производилось рентгенфлуоресцентным методом (ГИн СОРАН, г. УланУдэ). Концентрации редкоземельных элементов определялись методом сорбционно-атомноэмиссионного анализа с индуктивно-связанной плазмой (ГИН СОРАН, г. Улан-Удэ). Силикатный анализ проводился стандартным методом «мокрой химии» (ГИН СОРАН, г. Улан-Удэ).

Результаты. Установлена поперечная геохимическая зональность мезозойских вулканитов Забайкальского сегмента Монголо-Охотского складчатого пояса, выраженная в увеличении концентраций от фронтальной части вулканической дуги Монголо-Охотского складчатого пояса к тыловым ее частям концентраций K, Rb, Sr, Zr, Sb, Ba, Th, U, Cе отношений K/Na, Th/U, $\mathrm{Rb} / \mathrm{Sr}$, $\Sigma T R$. Отмечена пространственная приуроченность золоторудных месторождений к фронтальной части мезозойской вулканической дуги, полиметаллических и оловополиметаллических месторождений - к тыловым ее частям. Вулканиты полиметаллических месторождений характеризуются более значительной степенью окисленности железа и меньшей степенью диффреренциации магматических очагов. Окисленность железа (мера окислительных условий), соотнесенная к кремнекислотности пород в вулканитах золоторудных месторождений, варьирует от 0,19 до 0,90 (среднее значение - 0,53); в вулканитах полиметаллических месторождений - от 0,32 до 0,93 (среднее - 0,58). Такая закономерность типична для вулканитов островных дуг зон перехода континент-океан. Выявлено, что по мере удаления от фронтальной части вулканической дуги увеличиваются глубины генерации магм вулканитов Забайкальского сегмента Монголо-Охотского складчатого пояса. Такая закономерность характерна для Курило-Камчатской островной дуги. Это объясняется увеличением глубин зоны генерации магм по мере удаления от фронтальной части зоны субдукции. Глубины генерации магм вулканитов золоторудных месторождений, по данным Rb-Sr соотношений, составляют 15-20 км и более, полиметаллических и оловополиметаллических месторождений - 20-30 км и более.
\end{abstract}

\section{Ключевые слова:}

Вулканиты Забайкальского сегмента Монголо-Охотского складчатого пояса, поперечная геохимическая зональность, золоторудные и полиметаллические месторождения, глубины генерации магм, Восточное Забайкалье.

\section{Введение}

В рудных полях мезозойских месторождений Забайкальского сегмента Монголо-охотского складчатого пояса: Балейского, Погромного, Верхне-Алиинского, Андрюшкинского золоторудных месторождений, Нойон-Тологойского, Акатуевского, Кличкинского, Ново-Широкинского полиметаллических месторождений, Шерловогорского оловополиметаллического месторождения, широко развиты вулканогенные образования. В ближайшем обрамлении шовной зоны Монголо-Охотской сутуры (МОС) локализованы 30лоторудные проявления и месторождения, по мере удаления от нее - полиметаллические и оловополиметаллические месторождения. В рудных полях рассматриваемых месторождений вулканогенноосадочные отложения представлены породами шадаронской $\left(\mathrm{J}_{2-3}\right)$, мулинской $\left(\mathrm{J}_{2-3}\right)$ и приаргунской серий $\left(\mathrm{J}_{2-3}\right)$, образующими с комагматичными им интрузиями вулканоплутонические комплексы. Основной задачей исследования является установление условий формирования и отличительных особенностей мезозойских вулканических образований в рудных полях полиметаллических, оловополиметаллических и 30лоторудных месторождений Восточного Забайкалья.
На некоторых месторождениях эффузивы вмещают рудные образования.

\section{Фактический материал, методы исследования}

В основу статьи положен фактический материал, собранный автором в процессе тематических исследований по программам Института природных ресурсов, экологии и криологии СО РАН в 1998-2016 гг., опубликованные данные, а также материалы территориальных геологических фондов (г. Чита). Анализы были проведены в аналитических лабораториях Геологического института СО РАН (г. Улан-Удэ). Установление элементного состава пород проводилось с использованием ISP-AES и РФА методов анализов. Определение элементного состава проводилось на спектрометре ARL Perform X-4200 (аналитик Б.Ж. Жалсараев). Содержание петрогенных компонентов определялось стандартным химическим методом. Измерение концентраций редкоземельных элементов (Р3Э) проводилось на спектрометре OPTIMA 2000 DV (аналитики А.А. Цыренова, Т.И. Татьянкина). При расчете степени дифференциации магматических очагов интрузивных образований применялось значение 
европиевой аномалии $\mathrm{Eu} / \mathrm{Eu}^{*}=\mathrm{Eu}_{\mathrm{N}} /\left[\mathrm{Sm}_{\mathrm{N}} \times \mathrm{Gd}_{\mathrm{N}}\right]^{1 / 2}[1]$. Для оценки глубин формирования рудоносных магматических очагов использованы $\mathrm{Eu} / \mathrm{Sm}$ отношения в трактовке С.Ф. Винокурова [2].

\section{Краткая геологическая характеристика мезозойских вулканогенно-осадочных образований Восточного Забайкалья}

Образование мезозойских вулканитов Восточного Забайкалья связано с процессами столкновения Сибирского и Монголо-Китайского континентов в средне-позднеюрское время, приведшими к образованию сложной геодинамической обстановки калифорнийского типа [3]. Вдоль глубинной МонголоОхотской тектонической структуры происходило формирование обширных вулканических зон (рис. 1). По аналогии с Курильской островной дугой в мезозойских вулканических образованиях Забайкальского сегмента Монголо-Охотского складчатого пояса (ЗСМОСП) наблюдается поперечная петрогеохимическая зональность. Она выражена в увеличении от фронтальной зоны островной дуги к тыловым ее частям, в одинаковых по составу кремнезема вулканитах, таких элементов, как $\mathrm{K}, \mathrm{Ba}, \mathrm{Rb}, \mathrm{Sr} \mathrm{Sb}, \mathrm{Ce}$, суммы редкоземельных элементов ( $\sum$ Р3Э), отношений $\mathrm{Rb} / \mathrm{Sr}$, $\mathrm{K} / \mathrm{Na}[4,5]$. Наличие поперечной геохимической 30нальности в вулканитах островодужных систем описаны в многочисленных публикациях [6-15]. На природу образования геохимической зональности имеются различные точки зрения. Некоторые исследователи на основании изменения концентраций элементов от фронтальной части островной дуги к тыловой объясняют смешением компонентов субдукционных и мантийных флюидов [9], другие это связывают с изменением состава источника магматического флюида [7].

Во фронтальной зоне вулканических дуг локализуются золоторудные проявления, в тыловых частях вулканической дуги - полиметаллические месторождения $[16,17]$. Образование поперечной геохимической зональности объясняется увеличением глубины погружения субдуцируемой плиты [5].

Вулканиты шадоронской серии $\left(J_{2-3}\right)$, представленные андезибазальт-андезит-дацитовой ассоциацией пород с резким преобладанием андезитов с интрузиями шахтаминского комплекса $\left(\mathrm{J}_{2-3}\right)$, образуют вулканоплутонические структуры, в ареалах которых распространены золотые, золото-молибденовые и золотополиметаллические объекты.

Стратотип серии был выделен в Ундино-Даинской впадине. В разрезе серии выделяются три подсерии. Нижняя подсерия представлена андезитами, трахиандезитами, латитами, андезибазальтами, базальтами, туфогенно-осадочными породами, конгломератами, песчаниками, алевролитами. Мощность подсерии составляет 280-800 м. В разрезе средней подсерии в составе вулканитов преобладают трахидациты, андезидациты, трахиандезиты, кварцевые латиты и латиты с редкими прослоями эффузивов основного состава. Туфогенно-осадочные породы отмечаются в нижних и верхних частях разреза. Мощность подсерии - 280-1000 м. Верхняя подсерия по составу пород близка к нижней, но отличается большим разнообразием вулканитов. Эффузивы кислого и среднего состава находятся в подчиненном количестве. Туфы, туфогенно-осадочные породы слагают маломощные прослои. В Ундино-Даинской впадине шадаронская серия (соответственно снизу-вверх) представлена отложениями айрыкской, халкитойской и калтаганской свит. Те же подразделения В.В. Павлова в 1982 г. выделила в приаргунской серии [18]. Определения изотопного возраста вулканитов нижней толщи шадаронской серии в районе Ново-Широкинского месторождения показали $177 \pm 5$ млн лет, вулканитов верхней толщи - $156 \pm 6$ млн лет [19].

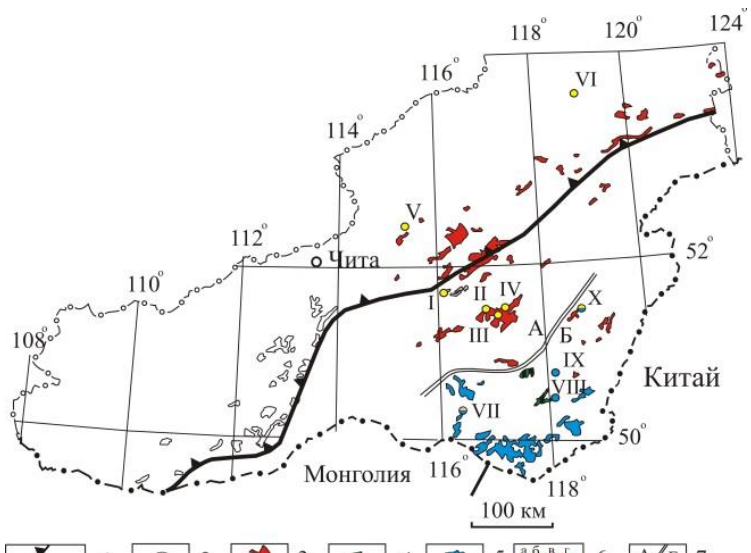

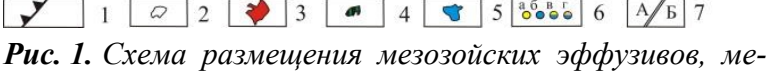
сторождений золота и полиметаллов Восточного Забайкалья: 1 - Монголо-Охотская сутура. Мезозойские вулканогенно-осадочные отложения $\left(J_{2-3}\right): 2$ - джаргалантуйской свиты $\left(J_{2-3}\right)$; 3 - шадаронской серии $\left(J_{2-3}\right) ; 4$ - мулинской серии (J2-3); 5 - приаргунской серии $\left(J_{2-3}\right)$; $6-$ Месторождения: I- Погромное (Au), II-Балейское (Аи), III - Андрюшкинское (Au), IV - ВерхнеАлиинское (Аи), V-Талатуйское (Аи), VI-Итакинское (Au), VII - Шерловогорское (Sn, Pb, Zn), VIII - Нойон-Тологойское (Pb, Zn), IX - Акатуевское (Pb, Zn), X-Ново-Широкинское (Pb, Zn, $\mathrm{Au})$; 7 - линия, разграничивающая вулканиты с геохимическими характеристиками фронтальной (А) и тыловой (Б) частей вулканической дуги

Fig. 1. Layout of Mesozoic effusive and gold and polymetals deposits in Eastern Transbaikalia: 1 - MongolOkhotsk suture. Mesozoic volcanogenic-sedimentary deposits $\left(J_{2-3}\right)$ of: $2-$ dzhargalantuysky suite $\left(J_{2-3}\right)$; 3 - shadaronsky series $\left(J_{2-3}\right) ; 4$ - mulinsky series $\left(J_{2-3}\right) ; 5$ - priargunsky series $\left(J_{2-3}\right) ; 6-$ Deposits: $I-$ Pogromnoe (Au), II - Baleyskoe (Au), III Andryushkinskoe (Au), IV - Verkhne-Aliinskoe (Au), $V$ - Talatuyskoe (Au), VI - Itakinskoe (Au), VII Sherlovogorskoe (Sn, Pb, Zn), VIII - NoyonTologoyskoe (Pb, Zn), IX - Akatuevskoe (Pb, Zn), $X$ - Novo-Shirokinskoe (Pb, Zn, Au); 7 - line demarcating vulcanites with geochemical characteristics of the frontal (A) and rear (B) parts of the volcanic arc

Вулканиты приаргунской серии $\left(J_{2-3}\right)$, в составе которых отмечаются породы трахибазальт-трахиандезибазальтолатит-трахидацитовой ассоциации, совместно с мон- 
цонит-граносиенит-гранитными интрузиями шахтаминского комплекса образуют вулканоплутонические структуры. Мощность отложений серии достигает 1800 м. Вулканогенный разрез приаргунской серии характеризуется преобладанием вулканитов основного и среднего составов при резко подчиненном количестве вулканитов кислого состава. В отличие от вулканитов шадаронской серии вулканиты приаргунской серии характеризуются большими концентрациями калия и более низкой магнезиальностью.

Вулканогенно-осадочные отложения мулинской серии $\left(J_{2-3}\right)$ распространены в Юго-Восточной части Забайкальского края в Кличкинском рудном районе. Они образуют небольшие по площади вулканические постройки (до $20 \mathrm{kм}^{2}$ ), состоящие из контрастных по составу лав - от кислых до основных. Абсарокитшошонит-трахитовая ассоциация вулканитов мулинской серии $\left(\mathrm{J}_{2-3}\right)$ в сочетании с эссексит-сиенитовыми интрузиями акатуйского комплекса образуют единые вулканоплутонические структуры. С процессами их образования связано формирование НойонТологойского и Акатуевского полиметаллических месторождений. Мулинская серия расчленена на залгатуйскую и кайлакскую свиты. В составе залгатуйской свиты преобладают вулканиты кислого и среднего составов, в составе кайлакской свиты - вулканиты среднего и основного составов. Осадочные и туфогенно-осадочные отложения в составе свит образуют прослои мощностью до нескольких десятков метров. Мощность отложений мулинской серии достигает $400 \mathrm{M.}$

Джаргалантуйская свита $\left(J_{2-3}\right)$ представлена преимущественно вулканитами кислого, реже среднего и основного составов. Общая мощность разреза составляет 400-700 м. Осадочные породы представлены в подчиненном количестве. Вулканиты свиты совместно с гранитоидами харалгинского комплекса $\left(\mathrm{J}_{2-3}\right)$ образуют крупные вулкано-плутонические комплек-

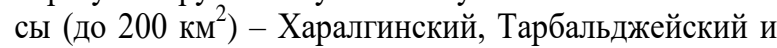
др. Изотопный возраст вулканитов (K-Ar метод) составляет 150-180 млн лет [18].

В Восточном Забайкалье известно более 180 позднемезозойских тектонических впадин. Они расположены вдоль зон глубинных разломов, образуя грабены и грабен-синклинали длиной от 3 до 300 км, шириной от 1 до 30 км. Впадины, как правило, вытянуты в северо-восточном направлении и выполнены осадочными и вулканогенно-осадочными отложениями. С позднемезозойскими тектоническими впадинами связаны крупные месторождения бурого угля (Харанорское, Красночикойское и др.) и каменного - (Апсатское, Букакачинское); железа - (Березовское), цеолитов - (Шивыртуйское, Холинское).

\section{Вулканиты рудных полей золоторудных месторождений}

Мезозойские вулканиты рудных полей золоторудных месторождений пространственно приурочены к шовной зоне МОС $[3,20]$.

В рудных полях Балейского, Апрелковского рудных узлов широко развиты вулканогенные образова- ния шадаронской серии $\left(\mathrm{J}_{2-3}\right)$. В Балейском рудном узле отложения шадаронской серии отмечаются в пределах Балейского, Андрюшкинского и ВерхнеАлиинского золоторудных месторождений, в Апрелковском рудном узле - на площади месторождения Погромное.

В Балейском рудном узле образование вулканитов шадаронской серии связано с процессами формирования Балейской вулканоплутонической купольной структуры, имеющей зональное строение. В центре этой структуры расположены гранитные штоки шахтаминского комплекса $\left(\mathrm{J}_{2-3}\right)$, далее, по мере продвижения к периферии структуры, развиты субвулканические штоки монцонито-диоритов, гранодиоритов, даек диоритовых порфиритов того же комплекса. К этой зоне приурочены месторождения и рудопроявления золота. По периферии кольцевой структуры развиты вулканогенно-осадочные отложения шадаронской серии $\left(\mathrm{J}_{2-3}\right)$.

В пределах Балейского рудного узла шадаронская серия подразделяется на три подсерии - нижнюю, среднюю и верхнюю. Отложения нижней подсерии представлены туфогенно-осадочными породами, песчаниками, алевролитами. В составе эффузивов отмечаются андезиты, андезибазальты, трахи-андезибазальты и базальты. Эффузивы средней подсерии представлены трахиандезитами, андезито-дацитами, латитами. Эффузивы основного состава отмечаются реже. Туфогенно-осадочные отложения развиты в нижней и верхней частях разреза подсерии. Среди эффузивов верхней подсерии наиболее широко развиты базальтоиды, менее распространены эффузивы среднего и кислого составов. Туфогенно-осадочные отложения слагают маломощные прослои. По минералогическим особенностям среди андезитов выделяются плагиоклазовые, амфиболовые, пироксеновые и амфиболпироксеновые разности - это породы с пилотакситовой структурой основной массы. Все они характеризуются наличием порфировых включений. Размер вкрапленников колеблется от 0,5 до 3 мм. В составе вкрапленников отмечаются: андезин, роговая обманка, авгит. В амфиболовых разностях содержатся повышенные содержания роговой обманки, а в амфиболпироксеновых разностях наряду с роговой обманкой развит пироксен. Дациты и андезидациты образуют редкие маломощные покровы мощностью 30-60 м. Порфировые вкрапленники в них сложены андезитом, биотитом, роговой обманкой, кварцем. В районе Андрюшкинского месторождения основное золотое оруденение приурочено к зонам скарнирования, развитым под экраном вулканитов шадаронской серии [21].

Вулканогенные образования шадаронской серии на площади месторождения Погромное отмечаются в разрозненных тектонических блоках на северозападном фланге месторождения. Они представлены базальтами, андезитами, трахиандезитами, дацитами и риолитами. В основании разреза шадаронской серии развит горизонт конломерато-брекчий. Изотопный возраст отложений шадаронской серии составляет от $148 \pm 3$ до $173 \pm 10$ млн лет [22]. 
В районе Талатуйского и Итакинского золоторудных месторождений отмечаются незначительные по площади выходы эффузивов. По данным геологосъемочных работ возраст эффузивов в районе Талатуйского месторождения соответствуют среднейпоздней юре, Итакинского месторождения - поздней юре.

\section{Вулканиты рудных полей полиметаллических и оло- вополиметаллических месторождений}

Среди полиметаллических и оловополиметаллических месторождений рассмотрим составы вулканогенных отложений, отмечаемых в рудных полях Нойон-Тологойского, Акатуевского, Ново-Широкинского и Шерловогорского месторождений.

В районах Нойон-Тологойского и Акатуевского месторождений широко представлены вулканиты мулинской серии $\left(\mathrm{J}_{2-3}\right)$. Они занимают небольшие площади - 1-20 км². Нойон-Тологойское полиметаллическое месторождение расположено в северозападной оконечности Западно-Урулюнгуевской впадины, Акатуевское месторождение - на северном плече Александрово-Заводской рифтогенной впадины.

Вулканиты мулинской серии контрастны по своему составу (от кислых до основных) с содержанием прослоек пирокластики и осадочных пород. Мулинская серия подразделяется на залгатуйскую свиту $\left(\mathrm{J}_{2}\right)$ умеренно кислого и среднего состава вулканитов и кайласскую $\left(\mathrm{J}_{2-3}\right)$ свиту вулканитов преимущественно среднего состава. Вулканогенно-осадочные отложения мулинской серии представлены чередованием многочисленных потоков андезито-дацитов, андезитов, андезибазальтов и базальтов, перемежающихся с горизонтами лавобрекчий, туфолав и маломощными прослоями туфов, алевролитов, песчаников и конгломератов. Доминируют в составе эффузивной толщи андезибазальты массивной и миндалекаменной текстур, для которых характерен порфировый облик при разнообразии структур основной массы (гиалопилитовая, пилотакситовая, интерсертальная, офитовая). Порфировые вкрапленники (плагиоклаз, пироксен) размером от 0,25 до 4,0 мм занимают до $30 \%$ объема породы; в миндалекаменных разностях присутствуют миндалины $\quad(5-30 \%)$ преимущественно кварцкарбонатного состава размером до 10-12 мм. В Нойон-Тологойском месторождении основное промышленное оруденение сосредоточено в мульдообразных погружениях, выполненное эффузивами залгатуйской свиты $\left(\mathrm{J}_{2-3}\right)$ [23]. Установлено, что Ar-Ar возраст амфиболов эффузивов кайласской свиты $\left(\mathrm{J}_{2-3}\right)$ района Акатуевского полиметаллического месторождения составляет $161 \pm 1,7$ млн лет [24].

Ново-Широкинское полиметаллическое месторождение приурочено к одноименной вулканоплутонической структуре. Широкинский рудный узел является единственным в Забайкалье, где известно промышленное золотополиметаллическое месторождение. В формировании Широкинской купольнокольцевой структуры основную роль играли глубоко дифференцированные шошонит-латитовые и известково-щелочные магмы [25]. В центральной части оча- гово-купольной структуры размещаются штоки магматических образований шахтаминского комплекса (граниты, гранодиориты), в периферийных частях располагаются эффузивные образования шадаронской серии. Эффузивные образования шадаронской серии $\left(\mathrm{J}_{2-3}\right)$ разделены на две толщи. Нижняя толща - существенно туфогенная, сложена туфопесчаниками, туфоалевролитами, туфобрекчиями, которые выше по разрезу сменяются покровами андезитов, андезибазальтов, их туфами и порфировыми разностями. Мощность толщи составляет 800-1000 м. Верхняя толща имеет однородный состав и представлена андезитами, андезибазальтами, кварцевоплагиоклазовыми порфиритами с прослоями их туфов и лавобрекчий. Изотопный возраст вулканитов нижней толщи (K-Ar метод) составляет 175 $\pm 9-168 \pm 7$ млн

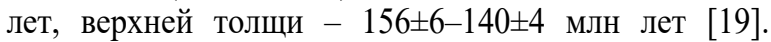
С покровами вулканитов тесно ассоциируют субвулканические тела диоритовых порфиритов шахтаминского комплекса.

В составе эффузивной толщи Широкинского рудного поля установлены амфибол-плагиоклазовые, пироксен-плагиоклазовые, плагиоклазовые, андезитовые и андезибазальтовые порфириты с прослоями лаво- и туфобрекчий, туфов, туффитов и туфопесчаников. Северо-западный фланг месторождения сложен, преимущественно, амфибол-плагиоклазовыми порфиритами, заключающими небольшие линзообразные прослои лавобрекчий и плагиоклазовых андезитовых порфиритов, быстро выклинивающихся по падению. Центральная и восточная части месторождения заняты в основном пироксен-плагиоклазовыми андезибазальтовыми порфиритами и их лавобрекчиями, часто чередующимися между собой. Породы нижней (туфогенно-осадочной) толщи вскрыты только в центральной части месторождения, на глубине. Представлены они песчаниками, туфопесчаниками и туфобрекчиями. Песчаники по простиранию быстро замещаются туфопесчаниками. Мощность прослоев песчаников 10-40м. Преобладающая часть полиметаллического оруденения развита в вулканогенных образованиях, в меньшей мере - в терригенных осадочных отложениях и интрузиях шахтаминского комплекса.

Позднеюрские эффузивные образования $\left(\mathrm{J}_{3}\right)$ в районе Шерловогорского олово-полиметаллического месторождения отмечаются в небольших тектонических выходах (до 0,25 км²) вдоль западного борта Харанорской впадины. В разрезе позднеюрских осадочно-вулканогенных отложений наблюдаются туфы трахианадезитов, конгломераты, лавы трахиандезитов, трахиандезибазальтов, аргиллиты. Трахиандезиты, трахиандезит-базальтовые порфириты имеют микрозернистую основную массу с вкрапленниками роговой обманки, амфиболов, размерами до 3 мм.

\section{Петрогеохимические особенности,}

условия формирования вулканитов рудных полей

В средне-позднеюрское время с закрытием Монголо-Охотского океанического бассейна коллизионные обстановки сменяются постколлизионными. 
Среди вулканитов золоторудных месторождений наибольшими концентрациями суммы РЗЭ ( $\sum \mathrm{TR}-$ 245,2-570,7), значительной дифференциацией магматического очага $\left(\mathrm{Eu} / \mathrm{Eu}^{*}-0,55-0,60\right)$, повышенными содержаниями тяжелых Р3Э [(La/Yb) n $-4,4-6,8]$, наименьшей магнезиальностью $(\mathrm{Mg} \#-0,10-0,25)$ и незначительными глубинами их образования $(\mathrm{Eu} / \mathrm{Sm}$ - 0,10-0,16) характеризуются породы месторождения Погромное (табл. 1). Минимальными содержаниями суммы РЗЭ характеризуются вулканиты Балейского месторождения ( $\left.\sum \mathrm{TR}-11,1-173,1\right)$, слабой дифференциаций магматического очага $\left(\mathrm{Eu} / \mathrm{Eu}^{*}-0,87-0,93\right)$ и существенной магнезиальностью $(\mathrm{Mg \#}-0,62-0,75)$ характеризуются вулканиты Андрюшкинского месторождения (табл. 1).

Значения геохимических характеристик вулканитов полиметаллических месторождений очень контрастны (табл. 2). Например, наибольшие значения суммы РЗЭ присущи вулканитам НойонТологойского месторождения ( $\sum \mathrm{TR}$ - 190,63-197,07), минимальные - ( $\mathrm{TR}$ - 19,2-38,5) вулканитам Шерловогорского месторождения (табл. 2). Эти данные указывают на то, что вулканиты рассматриваемых месторождений образованы из разноглубинных, в разной степени дифференцированых магматических очагов.

Геохимический состав вулканитов рудных полей золоторудных и полиметаллических месторождений характеризуется отличительными особенностями. Отмечаются следующие различные черты их геохимического состава:

1. Дискриминационная диаграмма $\mathrm{DF}_{1}-\mathrm{DF}_{2}$ вулканитов, развитых в шовной зоне МОС, указывает на их соответствие как островодужным, так и постколлизионным образованиям. Вулканиты, развитые на удалении от МОС, отвечают постколлизионным образованиям (рис. 2);

Эти данные указывают на то, что формирование вулканоплутонических образований в ЗСМОСП охватывает временные периоды островодужных и постколлизионных обстановок. При этом вблизи шовной зоны МОС вулканиты соответствуют как островодужным, так и постколлизиолнным обстановкам, на удалении от МОС - постколлизиолнным обстановкам (рис. 2).

2. На диаграмме $\mathrm{K}_{2} \mathrm{O}-\mathrm{SiO}_{2}$ вулканиты полиметаллических месторождений соответствуют высококалиевым известково-щелочным и шошонитовым сериям золоторудных месторождений - низкокалиевым толеитовым и среднекалиевым известково-щелочным сериям (рис. 3, табл. 1, 2);

3. Вулканиты полиметаллических месторождений характеризуются более значительной степенью окисленности железа и меньшей степенью дифференциации магматических очагов (рис. 4). Значения степени окисленности железа (мера окислительных условий), соотнесенные с кремнекислотностью пород в вулканитах золоторудных месторождений, варьируют от 0,19 до 0,68; в вулканитах полиметаллических месторождений - от 0,32 до 0,93 (табл. 1,2).
4. Вулканиты золоторудных месторождений характеризуются повышенными содержаниями тяжелых РЗЭ. Отношение $(\mathrm{La} / \mathrm{Yb})_{n}$ в вулканитах золоторудных месторождений колеблется от 4,4 до 18,2, в вулканитах полиметаллических месторождений - от 12,1 до 47,66 (табл. 1, 2).

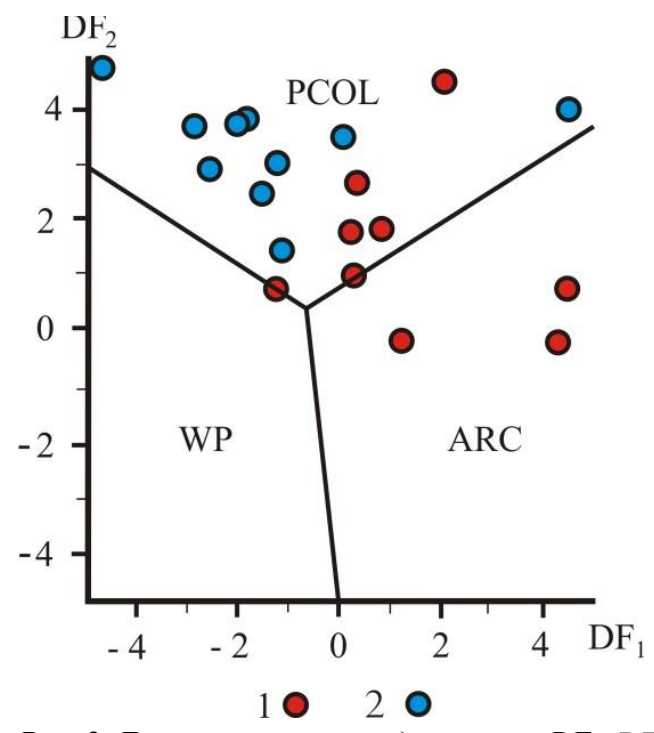

Puc. 2. Дискриминачионная диаграмма $D F_{1}-D F_{2}$ [26] вулканитов среднего состава Забайкальского сегмента Монголо-Охотского складчатого пояca. Породы: $P C O L-$ постколлизионные, WP - внутриплитные, ARC - островодужные. $\mathrm{DF}_{1}=-2,45605 \mathrm{Ln}\left(\mathrm{TiO}_{2} / \mathrm{SiO}_{2}\right)+1,11985 \mathrm{Ln}\left(\mathrm{Al}_{2} \mathrm{O}_{3} / \mathrm{SiO}_{2}\right)$ $2,22475 \mathrm{Ln}\left(\mathrm{Fe}_{2} \mathrm{O}_{3} / \mathrm{SiO}_{2}\right)+2,48861 \mathrm{Ln}\left(\mathrm{FeO} / \mathrm{SiO}_{2}\right)-$ $0,212024 \mathrm{Ln}\left(\mathrm{MnO} / \mathrm{SiO}_{2}\right)-0,06661 \mathrm{Ln}\left(\mathrm{MgO} / \mathrm{SiO}_{2}\right)+$ $1,29066 \mathrm{Ln}\left(\mathrm{CaO} / \mathrm{SiO}_{2}\right)-0,28377 \mathrm{Ln}\left(\mathrm{Na}_{2} \mathrm{O} / \mathrm{SiO}_{2}\right)_{-}$ $0,40211 \mathrm{Ln}\left(\mathrm{K}_{2} \mathrm{O} / \mathrm{SiO}_{2}\right)+0,030635 \mathrm{Ln}\left(\mathrm{P}_{2} \mathrm{O}_{5} / \mathrm{SiO}_{2}\right)-$ 11,43097347

$\mathrm{DF}_{2}=-0,57759 \mathrm{Ln}\left(\mathrm{TiO}_{2} / \mathrm{SiO}_{2}\right)-0,01121$

$\mathrm{Ln}\left(\mathrm{Al}_{2} \mathrm{O}_{3} / \mathrm{SiO}_{2}\right)+0,169125 \mathrm{Ln}\left(\mathrm{Fe}_{2} \mathrm{O}_{3} / \mathrm{SiO}_{2}\right)-$ $1,99798 \mathrm{Ln}\left(\mathrm{FeO} / \mathrm{SiO}_{2}\right)$

$1,72014 \mathrm{Ln}\left(\mathrm{MnO} / \mathrm{SiO}_{2}\right)+0,305275 \mathrm{Ln}\left(\mathrm{MgO} / \mathrm{SiO}_{2}\right)+$ $0,816018 \mathrm{Ln}\left(\mathrm{CaO} / \mathrm{SiO}_{2}\right)-1,791727$

$\mathrm{Ln}\left(\mathrm{Na}_{2} \mathrm{O} / \mathrm{SiO}_{2}\right)+0,871298 \mathrm{Ln}\left(\mathrm{K}_{2} \mathrm{O} / \mathrm{SiO}_{2}\right)+$ $0,335479 \mathrm{Ln}\left(\mathrm{P}_{2} \mathrm{O}_{5} / \mathrm{SiO}_{2}\right)-12,20158596$.

1 - вулканиты фронтальной части вулканической дуги, 2 - вулканиты тыловой части вулканической дуги

Fig. 2. Discriminatory $D F_{1}-D F_{2}[26]$ diagram of vulcanites of the average composition of the Transbaikalian segment of the Mongolo-Okhotsk folded belt. Breeds: $P C O L$ - post-collisional, WP - intraplate, ARCisland-arc. $\mathrm{DF}_{1}=-2,45605 \mathrm{Ln}\left(\mathrm{TiO}_{2} / \mathrm{SiO}_{2}\right)+$ $1,11985 \mathrm{Ln}\left(\mathrm{Al}_{2} \mathrm{O}_{3} / \mathrm{SiO}_{2}\right)-2,22475 \mathrm{Ln}\left(\mathrm{Fe}_{2} \mathrm{O}_{3} / \mathrm{SiO}_{2}\right)+$ 2,48861 Ln $\left(\mathrm{FeO} / \mathrm{SiO}_{2}\right)-0,212024 \mathrm{Ln}\left(\mathrm{MnO} / \mathrm{SiO}_{2}\right)-$ $0,06661 \mathrm{Ln}\left(\mathrm{MgO} / \mathrm{SiO}_{2}\right)+1,29066 \mathrm{Ln}(\mathrm{CaO} / \mathrm{SiO})_{2}-$ $-0,28377 \mathrm{Ln}\left(\mathrm{Na}_{2} \mathrm{O} / \mathrm{SiO}_{2}\right)-0,40211 \mathrm{Ln}\left(\mathrm{K}_{2} \mathrm{O} / \mathrm{SiO}_{2}\right)+$ $0,030635 \mathrm{Ln}\left(\mathrm{P}_{2} \mathrm{O}_{5} / \mathrm{SiO}_{2}\right)-11,43097347$; $\mathrm{DF}_{2}=-0,57759 \mathrm{Ln}\left(\mathrm{TiO}_{2} / \mathrm{SiO}_{2}\right)-0,01121 \mathrm{Ln}\left(\mathrm{Al}_{2} \mathrm{O}_{3} / \mathrm{SiO}_{2}\right)+$ $0,169125 \mathrm{Ln}\left(\mathrm{Fe}_{2} \mathrm{O}_{3} / \mathrm{SiO}_{2}\right)-1,99798 \mathrm{Ln}\left(\mathrm{FeO} / \mathrm{SiO}_{2}\right)-$

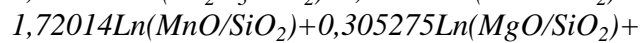
$0,816018 \mathrm{Ln}\left(\mathrm{CaO} / \mathrm{SiO}_{2}\right)-1,791727 \mathrm{Ln}_{\left(\mathrm{Na}_{2} \mathrm{O} / \mathrm{SiO}_{2}\right)+}$ $0,871298 \mathrm{Ln}\left(\mathrm{K}_{2} \mathrm{O} / \mathrm{SiO}_{2}\right)+0,335479 \mathrm{Ln}\left(\mathrm{P}_{2} \mathrm{O}_{5} / \mathrm{SiO}_{2}\right)-$ 12,20158596. 1 -volcanites of the frontal part of the volcanic arc, 2 -volcanites of the rear part of the volcanic arc 


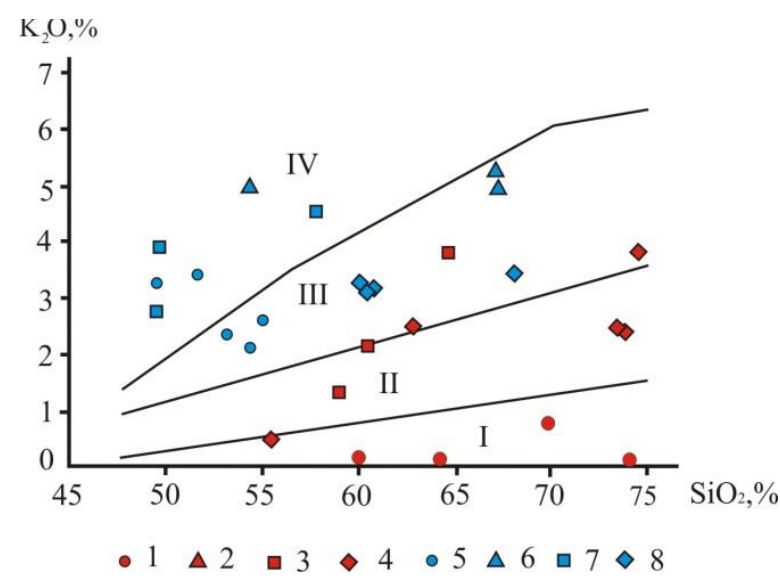

Pис. 3. Диаграмма $\mathrm{K}_{2} \mathrm{O} \quad \%-\mathrm{SiO}_{2} \%$ [27] вулканитов ЗСМОСП. Поля интрузивных серий на диаграмме: IV - шошонитовая, III - высококалиевая известково-щеелочная, II - средне-калиевая известково-щелочная, I - островодужная толеитовая. Эффузивы рудных полей месторождений: 1 Балейского, 2 - Погромного, 3 - ВерхнеАлиинского, 4 - Андрюшкинского, 5 - Ново- Широкинского, 6 - Нойон-Тологойского, 7 - Акатуевского, 8 - Шерловогорского

Fig. 3. $\mathrm{K}_{2} \mathrm{O} \%-\mathrm{SiO}_{2} \%$ [27] diagram of the volcanic rocks of the Trans-Baikal segment of the Mongol-Okhotsk fold belt. Fields of intrusive series on the diagram: $I V$ - Shoshonitic, III - high potassium calc-alkaline, II - medium potassium calc-alkaline, I - island arc tholeiitic. Effusion of ore fields deposits: 1 Baleisky, 2 - Pogromnoe, 3 -Verkhne-Aliinskoe, 4 Andryushkinsky, 5 - Novo-Shirokinskoe, 6 - NoyonTologoysky, 7 - Akatuevsky, 8 - Sherlovogorsky

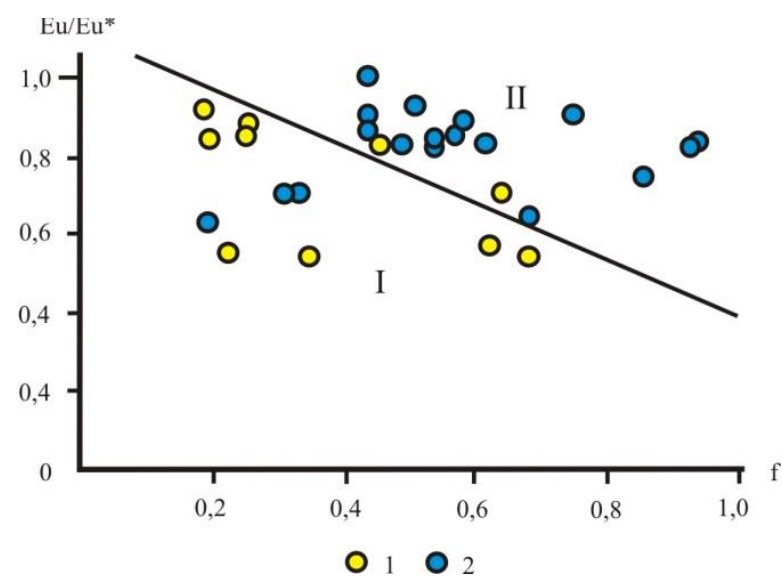

Puc. 4. Диаграмма $f-E u / E u^{*}$ [28, 29]. I - поля значений вулканитов золоторудных месторождений, II поля значений вулканитов полиметаллических месторождений; 1 - значения вулканитов золоторудных месторождений; 2 - значения вулканитов полиметаллических месторождений. $f=\left(\mathrm{Fe}_{2} \mathrm{O}_{3} / \mathrm{FeO}+\mathrm{Fe}_{2} \mathrm{O}_{3}\right)+0,38-\mathrm{SiO}_{2} / 200$ [29]

Fig. 4. $f-E u / E u^{*}$ diagram $[28,29] . I-$ the value field of volcanic rocks of gold deposits, II - the value field of volcanic rocks of polymetallic deposits; 1 - the values of volcanic rocks of gold deposits; 2 - the values of volcanic rocks of polymetallic deposits. $f=\left(\mathrm{Fe}_{2} \mathrm{O}_{3} / \mathrm{FeO}+\mathrm{Fe}_{2} \mathrm{O}_{3}\right)+0,38-\mathrm{SiO}_{2} / 200[29]$
Вулканиты мезозойских золоторудных и полиметаллических месторождений характеризуются разными глубинами генерации магматических очагов (рис. 5).

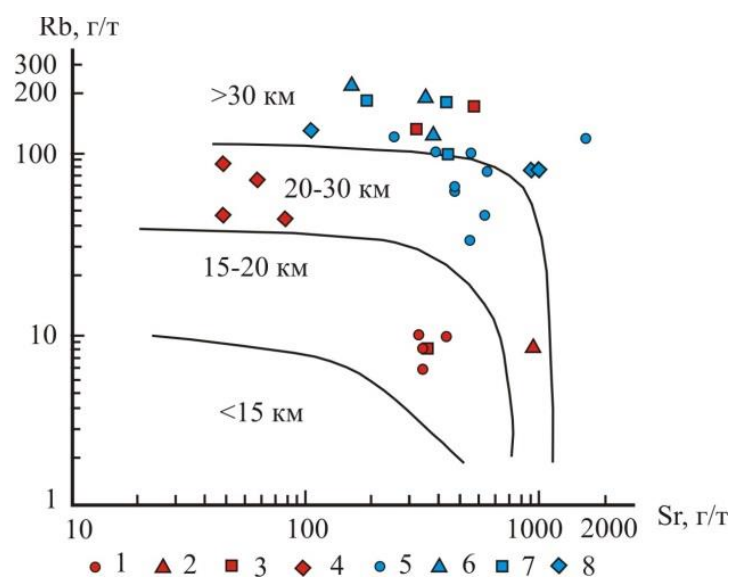

Pис. 5. Диаграмма $\mathrm{Rb}-\mathrm{Sr}$ [30] вулканитов рудных полей мезозойских месторождений Восточного Забайкалья. Сплошные линии - границь глубин генераиии магм. Условные обозначения на рис. 3

Fig. 5. Rb-Sr diagram [30] of volcanites from the ore fields of the Mesozoic deposits of Eastern Transbaikalia. Solid lines - the boundaries of magma generation depths. Symbols are in Fig. 3

Магматические очаги эффузивов Балейского месторождения находились на глубинах 15-20 км, эффузивов Андрюшкинского и Погромного месторождений - в 20-30 км, эффузивов Нойон-Тологойского, Акатуевского и Шерловогорского месторождений более 30 км.

Приведенные выше данные показывают, что модель петрохимической зональности ЗСМОСП соответствует таковой островодужного вулканизма. Ширина вулканических поясов зависит от угла падения субдицирующей плиты. Характерной особенностью магматизма субдукционных зон является латеральная магматическая зональность. Она выражена в смене по мере удаления от глубоководного желоба толеитовой серии на известково-щелочную и далее, в тыловой зоне вулканического пояса, - на шошонитовую серию. Такая же зональность типична для ЗСМОСП. В этом же направлении возрастают концентрации таких некогерентных элементов, как $\mathrm{K}, \mathrm{Rb}, \mathrm{Li}, \mathrm{Ba}, \mathrm{Sr}, \mathrm{Be}, \mathrm{U}$, $\mathrm{Th}, \mathrm{La}, \mathrm{Ce}$, и величин отношений $\mathrm{Rb} / \mathrm{Sr}, \mathrm{La} / \mathrm{Yb}, \mathrm{Sr} / \mathrm{Ce}$, $\mathrm{Th} / \mathrm{U}, \mathrm{Zr} / \mathrm{Y}$. Выявлено, что в вулканических дугах зон субдукции по мере удаления от глубоководного желоба медно-порфировое оруденение сменяется полиметаллическим и далее оловянным и вольфрамовым. Наличие поперечной геохимической зональности объясняется увеличением глубин залегания зоны Беньофа, которая увеличивается по мере удаления от глубоководных желобов [5].

Различия в ассоциациях и составе породообразующих минералов фронтальной и тыловой зон вулканических поясов связаны с различиями в химическом составе расплавов и с разными термодинамическими условиями их кристаллизации [5]. 
Известия Томского политехнического университета. Инжиниринг георесурсов. 2020. Т. 331. № 3. 123-134

Абрамов Б.Н. О поперечной петрогеохимической зональности мезозойских вулканитов в рудных полях Забайкальского ...

Таблица 1. Содержание петрогенных компонентов (\%) редких, рудных и редкоземельных элементов в эффузивах рудных полей золоторудных месторождений Восточного Забайкалья (г/m)

Table 1. Content of petrogenic components (\%) of rare, ore and rare-earth elements in effusions of ore fields gold ore deposits of Eastern Transbaikalia $(\mathrm{g} / \mathrm{t})$

\begin{tabular}{|c|c|c|c|c|c|c|c|c|c|c|c|c|c|c|c|c|c|c|}
\hline $\begin{array}{c}\text { № проб } \\
\text { Sample no. }\end{array}$ & 491 & 491-1 & 674-1 & $674-3$ & 675 & 812 & 813 & 817 & 723 & $723-1$ & 723-2 & $723-3$ & 313 & 314 & $314-1$ & 370 & 371 & 374 \\
\hline 1 & 2 & 3 & 4 & 5 & 6 & 7 & 8 & 10 & 11 & 12 & 13 & 14 & 15 & 16 & 17 & 18 & 19 & 20 \\
\hline $\mathrm{SiO}_{2}$ & 55,30 & 62,80 & 58,20 & 64,50 & 60,40 & 54,90 & 73,40 & 56,40 & 73,90 & 74,80 & 73,70 & 73,40 & 56,10 & 62,20 & 63,00 & 63,00 & 66,10 & 65,5 \\
\hline $\mathrm{TiO}_{2}$ & 0,63 & 0,77 & 0,80 & 0,92 & 0,75 & 0,60 & 0,75 & 0,40 & 0,22 & 0,24 & 0,24 & \begin{tabular}{|l|}
0,29 \\
\end{tabular} & \begin{tabular}{|l|}
0,81 \\
\end{tabular} & 0,52 & 0,53 & \begin{tabular}{|l|}
0,19 \\
\end{tabular} & 0,57 & 0,46 \\
\hline $\mathrm{Al}_{2} \mathrm{O}_{3}$ & 13,70 & 13,60 & 14,60 & 16,90 & 14,80 & 19,80 & 12,40 & 19,10 & 13,00 & 10,30 & 11,30 & 12,50 & \begin{tabular}{|l|}
14,30 \\
\end{tabular} & 14,50 & 14,60 & 15,40 & 14,20 & 13,80 \\
\hline $\mathrm{Fe}_{2} \mathrm{O}_{3}$ & 0,48 & 0,94 & 2,42 & 0,75 & 1,10 & 5,33 & 1,84 & 4,67 & 0,92 & 2,25 & 2,45 & 0,65 & 2,27 & 2,01 & 1,77 & 5,94 & 5,76 & 6,23 \\
\hline $\mathrm{FeO}$ & 5,11 & 4,56 & 4,25 & 5,07 & 5,27 & 3,94 & 1,08 & 4,19 & 2,07 & 1,41 & 1,30 & 2,44 & 5,04 & 2,80 & 2,56 & 0,87 & 1,00 & 1,20 \\
\hline $\mathrm{MnO}$ & 0,15 & 0,12 & 0,14 & 0,11 & 0,16 & 0,02 & 0,01 & 0,02 & 0,12 & 0,05 & 0,06 & 0,12 & 0,11 & 0,11 & 0,10 & 0,01 & 0,01 & 0,01 \\
\hline $\mathrm{MgO}$ & 8,86 & 4,53 & 5,96 & 1,96 & 5,96 & 4,02 & 3,51 & 4,01 & 0,13 & 0,16 & 0,12 & 0,54 & 6,66 & 3,06 & 2,75 & 4,52 & 4,02 & 3,72 \\
\hline $\mathrm{CaO}$ & 10,00 & 5,63 & 5,41 & 2,11 & 3,48 & 1,40 & 0,83 & 1,39 & 0,66 & 0,32 & 0,29 & 1,33 & 5,49 & 4,03 & 4,04 & 0,55 & 0,71 & 0,54 \\
\hline $\mathrm{Na}_{2} \mathrm{O}$ & 3,10 & 3,14 & 3,50 & 2,37 & 4,09 & 0,64 & 0,35 & 0,67 & 4,47 & 3,38 & 4,58 & 4,28 & 3,21 & 3,42 & 3,33 &, 62 &, 71 & 0,70 \\
\hline $\mathrm{K}_{2} \mathrm{O}$ & 0,44 & 2,66 & 1,23 & 3,93 & 2,13 & 0,01 & $0 ., 1$ & 0,01 & 2,45 & 3,80 & 2,41 & 1,95 & 2,35 & 3,28 & 3,59 & 0,10 &, 02 & 0,05 \\
\hline $\mathrm{K}_{2} \mathrm{O} / \mathrm{Na}_{2} \mathrm{O}$ & 0,14 & 0,85 & 0,35 & 1,66 & 0,52 & 0,02 & 0,03 & 0,01 & 0,55 & 1,12 & 0,53 & 0,45 & 0,73 & 0,96 & 1,08 & 0,16 & 0,03 & 0,07 \\
\hline $\mathrm{P}_{2} \mathrm{O}_{5}$ & 0,24 & 0,29 & 0,31 & 22 & 0,25 & 0,10 & 0,04 & 0,08 & $<0,1$ & $<0,1$ & $<0,1$ & $<0,1$ & 0,23 & 0,14 & 0,14 & 0,01 & 0,17 & 0,12 \\
\hline ппп & 1,51 & 1,25 & 2,68 & 1,36 & 2,03 & 2,20 & 1,68 & 2,18 & 1,93 & 2,62 & 2,86 & 1,89 & 3,02 & 3,35 & 3,02 & 1,92 & 1,75 & 1,07 \\
\hline$\sum$ & 99,52 & 100,3 & 99,50 & 100,2 & 100,4 & 92,96 & 95,90 & 93,12 & 99,87 & 99,33 & 99,33 & 99,39 & 99,39 & \begin{tabular}{|l|}
99,42 \\
\end{tabular} & 99,43 & 93,12 & 95,02 & 94,40 \\
\hline $\mathrm{Rb}$ & 8 & 50 & 126 & 250 & 164 & \begin{tabular}{|l|}
8 \\
\end{tabular} & \begin{tabular}{|l|}
10 \\
\end{tabular} & 6 & 44 & \begin{tabular}{|l|}
68 \\
\end{tabular} & \begin{tabular}{|l|}
39 \\
\end{tabular} & \begin{tabular}{|l|}
39 \\
\end{tabular} & \begin{tabular}{|l|}
110 \\
\end{tabular} & \begin{tabular}{|l|}
84 \\
\end{tabular} & \begin{tabular}{|l|}
83 \\
\end{tabular} & \begin{tabular}{|l|}
5,6 \\
\end{tabular} & 2,3 & 3 \\
\hline $\mathrm{Sr}$ & 920 & 600 & 320 & 6 & 580 & 366 & 424 & 342 & 78 & 68 & 47 & 86 & 503 & 519 & 525 & 296 & 257 & 217 \\
\hline $\mathrm{Zr}$ & 155 & 156 & 300 & 160 & 340 & 162 & 268 & 123 & 476 & 700 & 706 & 379 & 144 & 145 & 155 & 40 & 177 & 185 \\
\hline $\mathrm{Nb}$ & 6 & 5,4 & 1 & 7,3 & 12,2 & 4 & & - & 9,2 & 14,9 & 10,4 & 10,7 & 10 & 6,6 & 6,8 & & & 4,6 \\
\hline $\mathrm{Sb}$ & 4,8 & 4,6 & 3,8 & 33 & 2,8 & 5,4 & 14,3 & 1,9 & - & 374 & 100 & 1,6 & 27 & 7,0 & 2,5 & 13 & 5 & 9,6 \\
\hline $\mathrm{Ba}$ & 233 & 845 & 810 & 460 & 1020 & 25 & 88 & 11 & 625 & 817 & 597 & 554 & 792 & 1035 & 1134 & 19 & 17 & - \\
\hline Th & - & - & - & - & - & 8,0 & 42,0 & 6,0 & 9,0 & 10,0 & 8,8 & 4,8 & 9,0 & 8,2 & 8,5 & 15 & 3 & 9,2 \\
\hline 1 & 2 & 3 & 4 & 5 & 6 & 7 & 8 & 10 & 11 & 12 & 13 & 14 & 15 & 16 & 17 & 18 & 19 & 20 \\
\hline $\mathrm{La}$ & 24,1 & 31,3 & 28,6 & 51,0 & 25,2 & 8,7 & 36,1 & 3,5 & 51,0 & 67,4 & 73,1 & 35,9 & 39,3 & 30,1 & 30,6 & 2,37 & 4,86 & 4,83 \\
\hline $\mathrm{Ce}$ & 48,6 & 69,0 & 64,2 & 112,0 & 55,2 & 13,4 & 72,0 & 4,4 & 113,0 & 153,0 & 168,0 & 78,7 & 80,2 & 60,1 & 60,9 & 87 & 9,19 & 9,32 \\
\hline $\operatorname{Pr}$ & 5,6 & 8,6 & 7,35 & 12,7 & 5,9 & $<2$ & 6,6 & $<2$ & 15,0 & 20,8 & 22,8 & 10,1 & 9,10 & 5,90 & 5,86 & 0,50 & 1,00 & 1,00 \\
\hline $\mathrm{Nd}$ & 24,3 & 34,6 & 29,25 & 46,9 & 24,7 & 6,6 & 26,5 & 0,2 & 1,0 & 87,8 & 95,7 & 42,0 & 34,4 & 19,4 & 20,3 & 1,53 &, 45 & 3,91 \\
\hline $\mathrm{Sm}$ & 5,2 & 7,0 & 5,8 & 8,55 & 4,7 & 1,9 & 4,84 & $<1$ & 15,3 & 21,6 & 23,6 & 9,61 & 7,87 & 4,75 & 4,89 & 1,22 & 0,80 & 0,74 \\
\hline $\mathrm{Eu}$ & 1,3 & 1,57 & 1,24 & 1,96 & 1,07 & 0,30 & 0,91 & 0,15 & 2,46 & 3,79 & 4,09 & 1,51 & 1,80 & 1,06 & 1,08 & 0,07 & 0,25 & 0,18 \\
\hline $\mathrm{Gd}$ & 3,5 & 4,4 & & 5,75 & 2,9 & 1,6 & 3,2 & $<1$ & 13,0 & 19,1 & 20,4 & 7,37 & 5,20 & 3,66 & 3,53 & 0,85 & 12 & 0,75 \\
\hline $\mathrm{Tb}$ & $<0,5$ & 0,65 & 0,59 & 0,84 & 0,40 & $<0,5$ & 0,51 & $<0,5$ & 2,51 & 3,95 & 4,38 & 1,46 & 0,70 & 0,52 & 0,49 & 0,30 & 0,20 & 0,22 \\
\hline Dy & 2,4 & 3,2 & 2,65 & 4,3 & 2,2 & 1,1 & 2,8 & $<1$ & 12,7 & 19,1 & 19,0 & 7,01 & 3,50 & 2,65 & 2,78 & 0,25 & 1,06 & 0,85 \\
\hline Ho & $<0,5$ & 0,64 & 0,51 & 0,85 & 0,41 & $<0,5$ & 0,6 & $<0,5$ & 2,88 & 4,14 & 4,16 & 1,58 & 0,76 & 0,60 & 0,54 & 0,06 &, 26 & 0,18 \\
\hline Er & 1,15 & 1,5 & 1,35 & 2,35 & 1,1 & $<0,5$ & 1,7 & $<0,5$ & 8,06 & 11,4 & 11,6 & 4,31 & 1,89 & 1,57 & 1,56 & 0,30 & 0,57 & 0,59 \\
\hline $\mathrm{Tm}$ & $<, 3$ & $<0,3$ & $<0,3$ & 0,33 & $<0,3$ & $<0,3$ & $<0,3$ & $<0,3$ & 1,20 & 1,74 & 1,73 & 0,60 & 0,25 & 0,23 & 0,23 & 0,10 & 0,09 & 0,10 \\
\hline $\mathrm{Yb}$ & 1,0 & 1,4 & 1,1 & 2,2 & 0,96 & 0,57 & & 0,36 & 7,87 & 10,6 & 10,6 & 3,68 & 1,45 & 1,51 & 1,55 & 0,43 & 0,80 & 0,92 \\
\hline $\mathrm{Lu}$ & 0,15 & 0,19 & 0,20 & 0,36 & 0,15 & $<0,15$ & \begin{tabular}{|l|}
0,19 \\
\end{tabular} & $<0,15$ & 1,21 & 1,58 & 1,57 & 0,54 & 0,22 & 0,26 & 0,24 & 0,11 & 0,14 & 0,15 \\
\hline $\mathrm{Y}$ & 12,4 & 16,1 & 12,9 & 23,4 & 12,1 & 5,0 & 15,7 & 2,7 & 78,4 & 111,0 & 110,0 & 40,8 & 16,8 & 14,3 & 14,5 & 2,34 & 7,32 & 6,70 \\
\hline$\sum \mathrm{TR}$ & 129,7 & 180,2 & 159,3 & 273,5 & 137,0 & 39,2 & 173,1 & 11,1 & 385,6 & 537,0 & 570,7 & 245,2 & \begin{tabular}{|l|}
186,6 \\
\end{tabular} & 131,3 & 134,5 & 15,3 & 32,1 & 30,4 \\
\hline $\mathrm{Eu} / \mathrm{Eu}^{*}$ & 0,93 & 0,87 & 0,83 & 0,85 & 0,89 & 0,53 & 0,71 & - & 0,53 & 0,57 & 0,60 & \begin{tabular}{|l|}
0,55 \\
\end{tabular} & \begin{tabular}{|l|}
0,86 \\
\end{tabular} & 0,78 & 0,79 & 0,21 & 0,81 & 0,74 \\
\hline $\mathrm{Eu} / \mathrm{Sm}$ & 0,25 & 0,22 & 0,21 & 0,23 & 0,23 & 0,16 & 0,19 & - & 0,16 & 0,17 & 0,17 & 0,10 & 0,23 & 0,22 & 0,22 & 0,05 & 0,31 & 0,24 \\
\hline $\mathrm{Rb} / \mathrm{Sr}$ & 0,01 & 0,08 & 0,39 & 41,67 & 0,28 & 0,02 & 0,03 & 0,02 & 0,56 & 1,00 & 0,83 & 0,45 & 0,22 & 0,16 & 0,16 & 0,02 & 0,01 & 0,01 \\
\hline $\mathrm{Mg} \#$ & 0,75 & 0,62 & 0,68 & 0,40 & 0,65 & 0,54 & 0,78 & 0,54 & 0,10 & 0,13 & 0,10 & 0,25 & 0,67 & 0,61 & 0,60 & 0,73 & 0,70 & 0,66 \\
\hline $\mathrm{K}_{2} \mathrm{O} / \mathrm{Na}_{2} \mathrm{O}$ & 0,14 & 0,85 & 0,35 & 1,66 & 0,52 & 0,02 & 0,03 & 0,01 & 0,55 & 1,12 & 0,53 & 0,45 & 0,73 & 0,96 & 1,08 & 0,16 & 0,03 & 0,07 \\
\hline $\mathrm{f}$ & 0,19 & 0,24 & 0,45 & 0,19 & 0,25 & 0,68 & 0,64 & 0,63 & 0,34 & 0,62 & 0,66 & 0,22 & 0,41 & 0,48 & 0,48 & 0,89 & 0,90 & 0,89 \\
\hline
\end{tabular}

Примечание. Эффузивы: 491, 491-1 - Андрюшкинского месторождения; 674-1, 674-3, 675 - Верхне-Алиинского месторождения; 812, 813, 815, 817 - Балейского месторождения; 723, 723-1, 723-2, 723-3 -месторождения Погромное; 313, 314, 314-1 - Итакинского месторождения; 370, 371, 374 - Талатуйского месторождения.

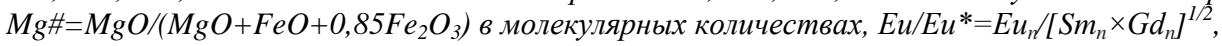

$f=\left(\mathrm{Fe}_{2} \mathrm{O}_{3} / \mathrm{FeO}+\mathrm{Fe}_{2} \mathrm{O}_{3}\right)+0,38-\mathrm{SiO}_{2} / 200$ [28], Прочерк - нет данных.

Note. Effusives: 491, 491-1 - Andryushkinsky deposit; 674-1, 674-3, 675 - Verkhne-Aliinsky deposit; 812, 813, 815, 817 Baleisky field; 723, 723-1, 723-2, 723-3 - Pogromnoe deposits, Itakinskigy deposit; 370, 371, 374 - Talatuysky deposit. $\mathrm{Mg \# =} \mathrm{MgO} /\left(\mathrm{MgO}+\mathrm{FeO}+0,85 \mathrm{Fe}_{2} \mathrm{O}_{3}\right)$ in molecular amounts, $\mathrm{Eu} / \mathrm{Eu}{ }^{*}=\mathrm{Eu} u_{n} /\left[\mathrm{Sm}_{n} \times G d_{n}\right] 1 / 2, f=\left(\mathrm{Fe}_{2} \mathrm{O}_{3} / \mathrm{FeO}+\mathrm{Fe}_{2} \mathrm{O}_{3}\right)+0,38-\mathrm{SiO}_{2} / 200$ [28], dash - no data. 
Известия Томского политехнического университета. Инжиниринг георесурсов. 2020. Т. 331. № 3. 123-134

Абрамов Б.Н. О поперечной петрогеохимической зональности мезозойских вулканитов в рудных полях Забайкальского ...

Таблица 2. Содержание петрогенных компонентов (\%) редких, рудных и редкоземельных элементов в эффузивах рудных полей полиметаллических месторождений Восточного Забайкалья (2/m)

Table 2. Content of petrogenic components (\%) of rare, ore and rare-earth elements in effusions of ore fields polymetallic deposits of Eastern Transbaikalia $(\mathrm{g} / \mathrm{t})$

\begin{tabular}{|c|c|c|c|c|c|c|c|c|c|c|c|c|c|c|c|c|c|c|c|}
\hline $\begin{array}{c}\text { № проб } \\
\text { Samples no. }\end{array}$ & 126 & 130 & 150 & 161 & 164 & 165 & 167 & 168 & 169 & 835 & 836 & 837 & 60 & 62 & 63 & 298 & 298-1 & 299 & 299-1 \\
\hline 1 & 2 & 3 & 4 & 5 & 6 & 7 & 8 & 9 & 10 & 11 & 12 & 13 & 14 & 15 & 16 & 17 & 18 & 19 & 20 \\
\hline $\mathrm{SiO}_{2}$ & 51,7 & 63,2 & 49,6 & 55,0 & 53,3 & 54,5 & 55,5 & 55,10 & 49,30 & 67,10 & 67,20 & 66,40 & 49,70 & 49,30 & 57,90 & 60,60 & 60,40 & 60,00 & 68,10 \\
\hline $\mathrm{TiO}_{2}$ & 0,68 & 0,36 & 0,81 & 0,74 & 0,72 & 0,73 & 0,70 & 0,70 & 0,68 & 0,44 & 0,40 & 0,39 & 0,70 & 0,71 & 0,74 & 0,85 & 0,86 & 0,86 & 0,61 \\
\hline $\mathrm{Al}_{2} \mathrm{O}_{3}$ & 12,2 & 13,3 & 11,4 & 14,5 & 14,5 & 14,2 & 14,70 & 14,70 & 14,20 & 15,90 & 16,40 & 15,70 & 10,60 & 10,70 & 12,90 & 17,10 & 17,30 & 17,20 & 14,90 \\
\hline $\mathrm{Fe}_{2} \mathrm{O}_{3}$ & 3,24 & 1,67 & 3,00 & 2,23 & 2,20 & 2,32 & 2,69 & 2,94 & 3,51 & 1,69 & 2,74 & 2,35 & 1,13 & 0,32 & 0,27 & 1,92 & 2,54 & 2,16 & 1,33 \\
\hline $\mathrm{FeO}$ & 54 & 2,12 & 1,94 & 4,75 & 5,00 & 4,86 & 3,50 & 3,61 & 4,40 & 0,43 & 0,35 &, 31 & 5,59 & 6,19 & 4,29 & 2,85 & 2,18 & 2,59 & 3,37 \\
\hline $\mathrm{MnO}$ & 0,11 & 0,33 & 0,53 & 0,14 & 0,12 & 0,13 & 0,09 & 0,10 & 0,13 & 0,06 & 0,03 & 0,09 & 0,30 & 0,31 & 0,12 & 0,08 & 0,08 & 0,08 & 0,08 \\
\hline $\mathrm{MgO}$ & 51 & 1,57 & 7,33 & 7,08 & 6,22 & 6,74 & 5,60 & 5,67 & 7,93 & 1,07 & 0,40 & 0,65 & 9,05 & 8,66 & 5,91 & 2,34 & 2,31 & 2,33 & 1,33 \\
\hline $\mathrm{CaO}$ & 6,38 & 2,26 & 4,76 & 7,78 & 8,36 & 7,99 & 6,73 & 6,68 & 4,20 & 0,52 & 0,64 & 2,45 & 14,97 & 17,56 & 10,55 & 4,45 & 4,55 & 4,68 & 1,04 \\
\hline $\mathrm{Na}_{2} \mathrm{O}$ & 25 & 1,04 & 0,28 & 3,24 & 3,46 & 3,50 & 2,85 & 2,88 & 1,93 & 1,38 & 3,41 & 2,63 & 0,66 & 0,80 & 0,71 & 4,06 & 4,12 & 4,43 & 3,07 \\
\hline $\mathrm{K}_{2} \mathrm{O}$ & 3,45 & 8,28 & 3,22 & 2,67 & 2,37 & 2,08 & 2,64 & 2,61 & 2,76 & 5,36 & 5,00 & 5,06 & 3,89 & 2,75 & 4,49 & 3,05 & 3,15 & 3,30 & 3,50 \\
\hline $\mathrm{P}_{2} \mathrm{O}_{5}$ & 0,22 & 0,12 & 0,32 & 0,20 & 0,20 & 0,21 & 0,19 & 0,19 & 0,17 & 0,22 & 0,19 & 0,19 & 0,16 & 0,16 & 0,17 & 0,32 & 0,32 & 0,32 & 0,14 \\
\hline ппп & 10,76 & 5,22 & 13,44 & 1,35 & 3,28 & 2,66 & 4,35 & 4,50 & 10,31 & 2,35 & 2,74 & 3,79 & 2,60 & 2,25 & 1,48 & 1,98 & 1,96 & 1,93 & 2,09 \\
\hline$\sum$ & 99,14 & 99,47 & 96,65 & 99,68 & 99,73 & 99,92 & 99,53 & 99,68 & 99,52 & 97,52 & 99,50 & 100,02 & 99,35 & 99,71 & 99,53 & 99,60 & 99,77 & 99,88 & 99,56 \\
\hline $\mathrm{Rb}$ & \begin{tabular}{|l|}
100 \\
\end{tabular} & 271 & 109 & 75 & 46 & 32 & 67 & \begin{tabular}{|l|}
65 \\
\end{tabular} & 114 & 248 & 161 & 188 & 166 & 100 & 170 & \begin{tabular}{|l|}
76 \\
\end{tabular} & \begin{tabular}{|l|}
77 \\
\end{tabular} & \begin{tabular}{|l|}
78 \\
\end{tabular} & 121 \\
\hline $\mathrm{Sr}$ & 571 & 390 & 1738 & 665 & 627 & 545 & 475 & 474 & 266 & 165 & 390 & 360 & 423 & 447 & 189 & 955 & 1000 & 945 & 105 \\
\hline $\mathrm{Zr}$ & 133 & 120 & 157 & 135 & 135 & 143 & 144 & 145 & 137 & 205 & 200 & 210 & 155 & 152 & 175 & 192 & 196 & 190 & 189 \\
\hline $\mathrm{Nb}$ & 8,7 & 4,5 & 7,0 & 6,2 & 7,2 & 8,1 & 7,0 & 6,8 & 6,6 & 10 & 9 & 9 & 16 & 16 & 14 & 9,5 & 9,4 & 10 & 10 \\
\hline $\mathrm{Sb}$ & 11 & 57 & 291 & 13 & - & - & - & - & 7 & 60 & 150 & 180 & - & - & - & - & 1,2 & 2,9 & 10,4 \\
\hline $\mathrm{Ba}$ & 578 & 2260 & 66 & 1457 & 595 & 818 & 590 & 598 & 723 & 905 & 900 & 1030 & 1564 & 988 & 1291 & 1135 & 1171 & 1113 & 560 \\
\hline Th & 10,0 & 5,6 & 8,4 & & 6,1 & 8,7 & 8,7 & 7,9 & 6,5 & 16,0 & 24,0 & 23,0 & 25,0 & 25,0 & 24,0 & 11,0 & \begin{tabular}{|l|}
9,6 \\
\end{tabular} & 8,6 & 10,0 \\
\hline $\mathrm{U}$ & 3,6 & 2,6 & 3,5 & 2,9 & 3,1 & 3,1 & 2,6 & 2,7 & 2,5 & - & - & - & 5,0 & 3,3 & 0,7 & 2,8 & 2,4 & 1,1 & 1,5 \\
\hline $\mathrm{La}$ & 0,2 & 17,8 & 3,4 & 24,9 & 22,3 & 27,2 & 24,6 & 25,8 & 26,2 & 46,4 & 50,1 & 7,8 & 25,3 & 39,3 & 54,8 & 38,5 & 39,1 & 39,7 & 35,8 \\
\hline $\mathrm{Ce}$ & 58,6 & 32,8 & 55,9 & 48,4 & 46,3 & 52,2 & 50,0 & 48 & 49,1 & 84,0 & 87,5 & 84,5 & 62,5 & 82,9 & 107,0 & 73,8 & 75,2 & 75,3 & 72,6 \\
\hline $\mathrm{Pr}$ & 7,3 & 3,85 & 6,5 & 5,6 & & 5,9 & 6,04 & \begin{tabular}{|l|}
5,8 \\
\end{tabular} & 5,6 & & & & 6,20 & 7,60 & 9,70 & 8,01 & 8,47 & 8,70 & 8,09 \\
\hline $\mathrm{Nd}$ & 26,8 & 14,7 & 28,7 & 23,1 & 21,4 & 25,1 & 24,0 & 23,3 & 23,4 & 30,4 & 30,1 & 29,5 & 31,5 & 35,6 & 38,2 & 39,2 & 39,2 & 38,7 & 36,0 \\
\hline $\mathrm{Sm}$ & 31 & 2,63 & 5,15 & 4,0 & & 4,5 & & & 4,5 & & & & 7,30 & 7,70 & 7,10 & 7,98 & 7,99 & 8,14 & 8,22 \\
\hline $\mathrm{Eu}$ & 1,26 & 0,71 & 1,4 & 1,16 & \begin{tabular}{|l|}
1,14 \\
\end{tabular} & 1,25 & 1,18 & 1,14 & 1,17 & 1,02 & 1,05 & 1,09 & 1,49 & 1,40 & 1,1 & 1,75 & 1,74 & 1,76 & 1,29 \\
\hline $\mathrm{Gd}$ & & 2,0 & 4,3 & & 3,6 & 4,3 & & 3,8 & 4,1 & & & & 6,1 & 6,3 & 4,3 & 5,12 & 5,18 & 5,09 & 6,11 \\
\hline $\mathrm{Tb}$ & 0,51 & 0,39 & 0,73 & 0,70 & 0,45 & 0,56 & 0,66 & 0,60 & 0,65 & $<0,5$ & $<0,5$ & $<0,5$ & 0,97 & 1,0 & 0,59 & 1,05 & 1,00 & 1,00 & 1,29 \\
\hline Dy & 2,96 & 1,38 & 2,9 & 3,0 & 3,0 & 3,06 & 3,2 & 3,07 & 2,9 & 2,1 & 1,95 & & 5,80 & 5,85 & 2,60 & 3,60 & 3,70 & 3,75 & 5,98 \\
\hline Ho & 0,51 & 0,25 & 0,44 & 0,54 & 0,55 & 0,50 & 0,62 & 0,55 & 0,47 & $<0,5$ & $<0,5$ & $<0,5$ & 1,20 & 1,20 & 0,50 & 0,77 & 0,73 & 0,82 & 1,42 \\
\hline $\mathrm{Er}$ & 1,4 & 0,70 & 1,2 & 1,45 & 1,5 & 1,4 & & 1,5 & 1,29 & 0,8 & & 0,78 & 3,90 & 3,80 & 30 & 1,92 & 1,93 & 2,16 & 3,98 \\
\hline $\mathrm{Tm}$ & 0,27 & 0,15 & \begin{tabular}{|l|l|}
0,19 \\
\end{tabular} & 9,23 & 0,32 & 0,24 & 0,30 & 0,26 & 0,19 & - & - & - & 0,58 & 0,54 & $<0,3$ & 0,24 & 0,22 & 0,29 & 0,68 \\
\hline $\mathrm{Yb}$ & 1,14 & 0,66 & 1,0 & 1,3 & 1,28 & 1,3 & 1,48 & 1,4 & 1,14 & \begin{tabular}{|l|}
0,71 \\
\end{tabular} & 0,73 & 0,72 & 3,5 & 3,4 & 1,1 & 1,55 & 1,54 & 1,71 & 3,93 \\
\hline $\mathrm{Lu}$ & 0,14 & 0,07 & \begin{tabular}{|l|}
0,09 \\
\end{tabular} & 0,14 & 0,15 & 0,16 & 0,17 & 0,15 & 0,14 & $<0,15$ & $<0,15$ & $<0,15$ & 0,34 & 0,39 & $<0,15$ & 0,24 & 0,24 & 0,28 & 0,62 \\
\hline $\mathrm{Y}$ & 15,4 & 7,5 & 14,5 & 16,6 & 15,4 & 16,5 & 18,0 & 17,3 & 16,0 & 8,8 & 8,7 & 9,6 & 36,3 & 38,8 & 17,2 & 19,2 & 19,5 & 20,5 & 38,5 \\
\hline$\sum$ Р3Э & 154,8 & 85,6 & 151,4 & 144,0 & 126,5 & 144,2 & 140,5 & 137,6 & 136,9 & 190,6 & 197,07 & 192,09 & 193,0 & 235,8 & 245,5 & 202,9 & 205,7 & 207,9 & 224,5 \\
\hline $\mathrm{Eu} / \mathrm{Eu}^{*}$ & 0,65 & 0,94 & 0,91 & 0,90 & 1,00 & 0,87 & 0,84 & 0,86 & 0,83 & 0,76 & 0,82 & 0,83 & 0,83 & 0,83 & 0,70 & 0,83 & 0,83 & 0,70 & 0,83 \\
\hline $\mathrm{Eu} / \mathrm{Sm}$ & 0,29 & 0,27 & 0,27 & 0,29 & 0,33 & 0,28 & 0,26 & 0,26 & 0,26 & 0,19 & 0,19 & 0,20 & 0,22 & 0,22 & 0,16 & 0,22 & 0,22 & 0,16 & 0,22 \\
\hline $\mathrm{Rb} / \mathrm{Sr}$ & 0,17 & 0,69 & 0,06 & 0,11 & 0,07 & 0,06 & 0,14 & 0,14 & 0,43 & 1,50 & 0,41 & 0,52 & 0,10 & 0,08 & 0,38 & 0,10 & 0,08 & 0,38 & 0,10 \\
\hline $\mathrm{Mg} \#$ & 0,75 & 0,75 & 0,69 & 0,73 & 0,71 & 0,72 & 0,69 & 0,68 & 0,71 & 0,64 & 0,53 & 0,50 & 0,38 & 0,38 & 0,56 & 0,38 & 0,38 & 0,56 & 0,38 \\
\hline $\mathrm{Na}_{2} \mathrm{O} / \mathrm{K}_{2} \mathrm{O}$ & 0,65 & 0,12 & 0,08 & 1,21 & 1,46 & 1,68 & 1,07 & 1,10 & 0,70 & 0,26 & 0,68 & 0,52 & 1,31 & 1,34 & 0,88 & 1,31 & 1,34 & 0,88 & 1,31 \\
\hline $\mathrm{f}$ & 0,68 & 0,50 & 0,74 & 0,43 & 0,43 & 0,43 & 0,53 & 0,56 & 0,57 & 0,85 & 0,92 & 0,93 & 0,61 & 0,53 & 0,32 & 0,61 & 0,53 & 0,32 & 0,61 \\
\hline
\end{tabular}

Примечание. Эффузивы: 126, 130, 150, 161, 164, 165, 167, 168, 169 - Ново-Широкинского месторождения; 835, 836, 837 - Нойон-Тологойского месторождения; 60, 62, 63 - Акатуевского месторождения; 298, 298-1, 299, 299-1 Шерловогорского месторождения.

Note. Effusives: 126, 130, 150, 161, 164, 165, 167, 168, 169 - Novo-Shirokinsky field; 835, 836, 837 - Noyon-Tologoysky field; 60, 62, 63 -Akatuevsky field; 298, 298-1, 299, 299-1 - Sherlovogorsky field. 


\section{Заключение}

Таким образом, в Восточном Забайкалье в среднепозднеюрский период при коллизионных и постколлизионных процессах с сопутствующей вулканоплутонической деятельностью происходило формирование мезозойских вулканических образований. Анализ геохимического состава вулканических образований указывает на наличие поперечной геохимической зональности. От фронтальной зоны мезозойской вулканической дуги Забайкальского сегмента МонголоОхотской сутуры к тыловым ее частям отмечается увеличение концентраций $\mathrm{K}, \mathrm{Ba}, \mathrm{Rb}, \mathrm{Sr} \mathrm{Sb}, \mathrm{Ce}$, суммы редкоземельных элементов, отношений $\mathrm{Rb} / \mathrm{Sr}, \mathrm{K} / \mathrm{Na}$. Одновременно с этим увеличиваются глубины генерации магм вулканитов. Аналогичная зональность

\section{СПИСОК ЛИТЕРАТУРЫ}

1. Интерпретация геохимических данных / под ред. Е.В. Склярова. - М.: Интермет Инжиниринг, 2001. - 288 с.

2. Винокуров С.Ф. Европиевые аномалии в рудных месторождениях и их геохимическое значение // Доклады Академии Наук. - 1996. - Т. 346. - № 6. - С. 792-795.

3. Геодинамика западной части Монголо-Охотского пояса и тектонические позиции рудных проявлений золота в Забайкалье / Ю.А. Зорин, В.Г. Беличенко, И.Г. Рутштейн, Л.Д. Зорина, А.М. Спиридонов // Геология и геофизика. - 1998. - Т. 39. № 11. - C. 104-112.

4. Volunetz O.N. Geochemical types, petrology and genesis of late Cenjzoic volcanic rocks from the Kurile-Kamchatka island-arc system // International Geology Review. - 1994. - V. 36. P. 373-405.

5. Цуканов Н.В. Позднемеловой-эоценовый вулканизм Кроноцкой палеодуги (Камчатка) // Вестник КРАУНЦ. Науки о Земле. - 2018. - № 2. - Вып. № 38. - С. 5-17.

6. Rear-arc vs. arc-front volcanoes in the Katmai reach of the Alaska Peninsula: a critical appraisal of across-arc compositional variation / W. Hildreth, J. Fierstein, D.F. Siems, J.R. Budahn, J. Ruíz // Contributions to Mineralogy and Petrology. - 2004. - V. 147. P. 243-275.

7. Bindeman I.N., Bailey J.C. Trace elements in anorthite megacrysts from the Kurile Island Arc: a window to across arc geochemical variations in magma compositions // Earth and Planetary Science Letters. - 1999. - V. 69. - P. 209-226.

8. Kimura J.-I., Yoshida T. Contributions of slab fluid, mantle wedge and crust to the origin of Quaternarylavas in the NE Japan arc / Journal of Petrology. - 2006. - V. 47. - P. 2185-2232.

9. Ishikawa T., Tera F. Source, composition and distribution of the fluid in the Kurile mantle wedge: Constraints from across-arc variations of $\mathrm{Br} / \mathrm{Nb}$ and $\mathrm{B}$ isotopes // Earth and Planetary Science Letters. - 1997. - V. 152. - P. 123-138.

10. Bailey J.C. Role of subducted sediments in the genesis of KurilKamchatka island arc basalts: Sr isotopic and elemental evidence // Geochemical Journal. - 1996. - V. 30. - P. 289-321.

11. Bailey J.C., Frolova T.I., Burikova I.A. Mineralogy, geochemistry and petrogenesis of Kurile island-arc basalts // Contributions to Mineralogy and Petrology. - 1989. - V. 102. - P. 265-280.

12. Stern R.J. Subduction initiation: spontaneous and induced // Earth and Planetary Letters. 2004. - V. 226. - P. 275-292.

13. Drastic shift in lava geochemistry in the volcanic-front to rear-arc region of the Southern Kamchatka subduction zone: evidence for the transition from slab surface / S. Duggen, M. Portnyagin, J. Baker, D. Ulfbeck, K. Hoernle, D. Garbe-Schönberg, N. Grassineau // Geochimic et Cosmochimica Acta. - 2007. V. 71. - P. 452-480.

14. Defant M.J., Jackson T.E., Drummont M.S. The geochemistry of young volcanism throughout western Panama and southeastern Costa Rica: an overview // Journal of the Geological Society (London). $-1992 .-$ V. 149. - P. 569-579. вулканических образований характерна для Курильской островной дуги. Возникновение поперечной геохимической зональности и увеличение глубин генераций магм связывается с увеличением глубин погружения субдуцируемой плиты. Установлено, что вулканиты полиметаллических месторождений относительно вулканитов золоторудных месторождений характеризуются более значительной степенью окисленности железа и меньшей степенью дифференциации магматических очагов. Выявлена пространственная приуроченность золоторудных месторождений к фронтальной части мезозойской вулканической дуги, полиметаллических и оловополиметаллических месторождений - к тыловым ее частям.

15. Generation of silicic melts in the early Izu-Bonin arc recorded by detrital zircons in proximal arc volcaniclastic rocks from the Philippine Sea / A.P. Barth, K. Tani, S. Meffre, J.L. Wooden, M.A. Coble, J.L. Wooden, R.J. Arculus, O. Ishizuka, J.T. Shukle // Geochemistry, Geophysics, Geosystems. - 2017. - V. 18. P. 3576-3591.

16. Вулканогенные пояса окраинно-морской литосферы северовостока России и их рудоносность / А.А. Сидоров, А.В. Волков, А.Д. Чехов, Н.Е. Савва, В.Ю. Алексеев, К.В. Уютнов // Вулканология и сейсмология. - 2011. - № 6. - С. 21-35.

17. Галямов А.Л., Волков А.В., Сидоров А.А. Пространственные соотношения золоторудных месторождений и мелового гранитоидного магматизма Чукотки // Доклады Академии Наук. - 2018. - Т. 482. - № 4. - С. 421-425.

18. Объяснительная записка к геологической карте масштаба 1:500000. - Чита, ГГУП «Читагеолсъемка», 1997. - 239 с.

19. Зорина Л.Д., Санин Б.П. Петрохимия и геохимические особенности Широкинского вулканоплутонического комплекса (Восточное Забайкалье) // Геохимия. - 1980. - № 2. - С. 217-225.

20. Семинский Ж.В. Рудные пояса Байкало-Забайкальского региона. Ч. II // Известия Сибирского отделения РАЕН. Геология, поиски и разведка полезных ископаемых. 2018. - Т. 41. № 2. - C. 9-28.

21. Абрамов Б.Н. Андрюшкинское золоторудное месторождение: геохимические особенности пород и руд (Восточное Забайкалье) // Руды и металлы. - 2016. - № 3. - С. 15-22.

22. Ступак Ф.М., Кудряшова В.А., Лебедев В.А. О юрском вулканизме и вулканах Шадаронской впадины Юго-Восточного Забайкалья // Вулканология и сейсмология. - 2016. - № 2. C. $18-31$.

23. Абрамов Б.Н. Нойон-Тологойское полиметаллическое месторождение: петрогеохимические особенности состава пород и руд // Геология и геофизика. 2017. - Т. 58. - № 2. - С. 215-230.

24. Кхлиф Н., Сасим С.А., Андреева Ю.С. Вещественные особенности и петрогенезис вулканитов кайласской и тургинской свит Александрово-Заводской рифтогенной впадины ЮгоВосточного Забайкалья // Известия Иркутского государственного университета. Серия: Науки о Земле. - 2017. - Т. 18. C. $108-129$.

25. Широкинский рудный узел (Восточное Забайкалье): условия образования, геохимия пород и руд, связь с магматизмом / Б.Н. Абрамов, Ю.А. Калинин, К.Р. Ковалев, В.Ф. Посохов // Известия Томского политехнического университета. Инжиниринг георесурсов. - 2017. - Т. - 328. - № 6. - С. 6-17.

26. Великославинский С.Д., Крылов Д.П. Геодинамическая типизация магматических пород среднего состава по геохимическим данным // Петрология. - 2015. - Т. 23. - № 5. - С. 451-458.

27. Peccerillo R., Taylor S.R. Geochemistry of Eocene calk-alkaline volcanic rocks from the Kastamonu area, northern Turkey // Contributions to Mineralogy and Petrology. - 1976. - V. 58. P. 63-81.

28. Меркулова Т.В., Мишин Л.Ф. Окислительно-восстановительные процессы в мезозойско-кайнозойских вулканоплутонических системах и их роль в формировании региональных гравитаци- 
Известия Томского политехнического университета. Инжиниринг георесурсов. 2020. Т. 331. № 3. 123-134

Абрамов Б.Н. О поперечной петрогеохимической зональности мезозойских вулканитов в рудных полях Забайкальского ...

онных и магнитных аномалиях Дальнего Востока // Тихоокеанская геология. - 2015. - Т. 34. - № 6. - С. 112-124.

29. Мишин Л.Ф., Романовский Н.П. Окислительно-восстановительные обстановки формирования и металлогеническая специализация рудно-магматических систем юга Дальнего Востока // Тихоокеанская геология. - 1992. - № 6. - С. 31-42.
30. Вулканизм Южного Урала / И.В. Серавкин, А.М. Косарев, Л.И. Салихов, С.Е. Знаменский, З.И. Родичев, М.В. Рыкус. М.: Наука, 1990. - 197 с.

Поступила 22.02.2020 2.

\section{Информация об авторах}

Абрамов Б.Н., доктор геолого-минералогических наук, ведущий научный сотрудник лаборатории геохимии и рудогенеза Института природных ресурсов, экологии и криологии СО РАН. 


\title{
UDC $559.424(571.55)$ \\ ON TRANSVERSE PETROGEOCHEMICAL ZONALITY OF MESOZOIC VOLCANITES IN THE ORE FIELDS OF THE TRANSBAIKALIAN SEGMENT OF THE MONGOLO-OKHOTSK FOLD BELT
}

\author{
Bair N. Abramov, \\ b_abramov@mail.ru \\ Institute of Natural Resources, Ecology and Cryology, SB RAS, \\ 16a, PO box 1032, Nedorezov street, Chita, 672014, Russia.
}

\begin{abstract}
The relevance of the work is caused by the need to study the regularities of mineralization formation in the Transbaikalian segment of the Mongol-Okhotsk fold belt.

The aim of the work is to establish the conditions of formation, to identify the presence of transverse geochemical zonality in the Mesozoic volcanic arc of the Transbaikalian segment of the Mongol-Okhotsk fold belt.

Methods. The elemental composition of the rock was determined by the X-ray fluorescence method (GIN SB RAS, Ulan-Ude). Concentrations of rare-earth elements were determined by the method of sorption-atomic emission analysis with inductive-plasma (GIN SB RAS, Ulan-Ude). Silicate analysis was performed by the standard method of "wet chemistry» (GIN SB RAS, Ulan-Ude).

Results. The author has established the transverse geochemical zonality of the Mesozoic volcanites of the Transbaikalian segment of the Mongol-Okhotsk folded belt, expressed in increasing concentrations from the frontal part of the volcanic arc of the Mongol-Okhotsk folded belt to its rear parts concentrations of $K, R b, S r, Z r, S b, B a, T h, U, C e$ relations $K / N a, T h / U, R b / S r, \Sigma T R$. The spatial confinement of gold deposits to the frontal part of the Mesozoic volcanic arc, polymetallic and tin-polymetallic deposits to its rear parts is noted. Volcanites of polymetallic deposits are characterized by a higher degree of iron differentiation and a low degree of differentiation of magma chambers. Iron acid (a measure of oxidation states), the ratio to silicic acid rocks in the volcanites of gold ore deposits, varies from 0,19 to 0,90 (the average value is 0,53 ), in volcanites of polymetallic deposits - from 0,32 to 0,93 (average - 0,58). Such a pattern is typical for volcanics of island arcs of the continent-ocean transition zones. It was revealed that as the distance from the frontal part of the volcanic arc increases, the depths of magma generation of volcanic rocks of the Transbaikalian segment of the Mongol-Okhotsk folded belt increase. Such a pattern is characteristic to the Kuril-Kamchatka island arc. This is explained by increase in the depths of the magma generation zone with increasing distance from the frontal part of the subduction zone. The depths of magma generation in volcanic gold deposits, according to $\mathrm{Rb}-\mathrm{Sr}$ ratios, are $15-20 \mathrm{~km}$ or more, and polymetallic and tin-polymetallic deposits are $20-30 \mathrm{~km}$ or more.
\end{abstract}

\section{Key words:}

Volcanites of the Transbaikalian segment of the Mongol-Okhotsk fold belt, transverse geochemical zonality, gold and polymetallic deposits, magma generation depths, Eastern Transbaikalia.

\section{REFERENCES}

1. Interpretatsiya geokhimicheskikh dannykh [Interpretation of geochemical data]. Ed. by E. V. Sklyarov. Moscow, Intermet Engineering Publ., 2001. 288 p.

2. Vinokurov S.F. Evropievye anomalii v rudnykh mestorozhdeniyakh i ikh geokhimicheskoe znachenie [Europium anomalies in ore deposits and their geochemical significance]. Doklady Earth Sciences, 1996, vol. 346, no. 6, pp. 792-795.

3. Zorin Yu.A., Belichenko V.G., Rutshtein I.G., Zorina L.D., Spiridonov A.M. Geodinamika zapadnoy chasti mongolo-Okhotskogo poyasa i tektonicheskie pozitsii rudnykh proyavleniy zolota $\mathrm{v} \mathrm{Za}-$ baykalye [Geodynamics of the Western part of the MongolOkhotsk belt and tectonic position of ore manifestations of gold in Transbaikalia]. Russian Geology and Geophysics, 1998, vol. 39, no. 11, pp. 104-112.

4. Volunetz O.N. Geochemical types, petrology and genesis of late Cenjzoic volcanic rocks from the Kurile-Kamchatka island-arc system. International Geology Review, 1994, vol. 36, pp. 373-405.

5. Tsukanov N.V. Upper Cretaceous-Eocene volcanism of the Kronotskiy paleoarc (Kamchatka). Bulletin of the Kamchatka regional organization educational and scientific center. Series: Earth Sciences, 2018, no. 2 (38), pp. 5-21. In Rus.

6. Hildreth W., Fierstein J., Siems D.F., Budahn J.R., Ruíz J. Reararc vs. arc-front volcanoes in the Katmai reach of the Alaska, Peninsula: a critical appraisal of across-arc compositional variation. Contributions to Mineralogy and Petrology, 2004, vol. 147, pp. 243-275.

7. Bindeman I.N., Bailey J.C. Trace elements in anorthite megacrysts from the Kurile Island Arc: a window to across arc geochemical variations in magma compositions. Earth and Planetary Science Letters, 1999, vol. 69, pp. 209-226.
8. Kimura J.-I., Yoshida T. Contributions of slab fluid, mantle wedge and crust to the origin of Quaternarylavas in the NE Japan arc. Journal of Petrology, 2006, vol. 47, pp. 2185-2232.

9. Ishikawa T., Tera F. Source, composition and distribution of the fluid in the Kurile mantle wedge: Constraints from across-arc variations of $\mathrm{Br} / \mathrm{Nb}$ and $\mathrm{B}$ isotopes. Earth and Planetary Science Letters, 1997, vol. 152, pp. 123-138.

10. Bailey J.C. Role of subducted sediments in the genesis of KurilKamchatka island arc basalts: $\mathrm{Sr}$ isotopic and elemental evidence. Geochemical Journal, 1996, vol. 30, pp. 289-321.

11. Bailey J.C., Frolova T.I., Burikova I.A. Mineralogy, geochemistry and petrogenesis of Kurile island-arc basalts. Contributions to Mineralogy and Petrology, 1989, vol. 102, pp. 265-280.

12. Stern R.J. Subduction initiation: spontaneous and induced. Earth and Planetary Letters, 2004, vol. 226, pp. 275-292.

13. Duggen S., Portnyagin M., Baker J., Ulfbeck D., Hoernle K., GarbeSchönberg D., Grassineau N. Drastic shift in lava geochemistry in the volcanic-front to rear-arc region of the Southern Kamchatka subduction zone: evidence for the transition from slab surface. Geochimic et Cosmochimica Acta, 2007, vol. 71, pp. 452-480.

14. Defant M.J., Jackson T.E., Drummont M.S. The geochemistry of young volcanism throughout western Panama and southeastern Costa Rica: an overview. Journal of the Geological Society (London), 1992, vol. 149, pp. 569-579.

15. Barth A.P., Tani K., Meffre S., Wooden J.L., Coble M.A., Wooden J.L., Arculus R.J., Ishizuka O., Shukle J.T. Generation of silicic melts in the early Izu-Bonin arc recorded by detrital zircons in proximal arc volcaniclastic rocks from the Philippine Sea. Geochemistry, Geophysics, Geosystems, 2017, vol. 18, pp. 3576-3591.

16. Sidorov A.A., Volkov A.V., Chekhov A.D, Savva N.E., Alekseev V.Yu., Uyutnov K.V. Volcanogenic belts of the Marginal sea lithosphere in the Russian Northeast and their ore potential. 
Journal of Volcanology and Seismology, 2011, vol. 5, no. 6, pp. 386-398. In Rus.

17. Galyamov A.L., Volkov A.V., Sidorov A.A. Prostranstvennye sootnosheniya zolotorudnykh mestorozhdeniy i melovogo granitoidnogo magmatizma Chukotki [Spatial relations between gold deposits and Cretaceous granitoid magmatism in Chukotka]. Doklady Earth Sciences, 2018, vol. 482, no. 4, pp. 42-425.

18. Obyasnitelnaya zapiska $k$ geologicheskoy karte masshtaba 1:500000 [Explanatory note to the geological map scale 1:500000] Chita, Chitageolsemka Publ., 1997. 239 p.

19. Zorina L.D., Sanin B.P. Petrokhimiya i geokhimicheskie osobennosti Shirokinskogo vulkanoplutonicheskogo kompleksa (Vostochnoye Zabaykalye) [Petrochemistry and geochemical features of the Shirokinskiy volcanoplutonic complex (Eastern Transbaikalia)]. Geochemistry International, 1980, no. 2, pp. 217-225.

20. Seminsky Zh.V. Ore belts of the Baikal-Transbaikal region. P. II Proc. of the Siberian Department of the Section of Earth Sciences RANS. Geology, Exploration and Development of Mineral Deposits, 2018, vol. 41, no. 2, pp. 9-28. In Rus.

21. Abramov B.N. Andryushkinsky gold deposit: geochemical features of rocks and ores (Eastern Transbaikalia). Ores and metals, 2016, no. 3, pp. 15-22. In Rus.

22. Stupak F.M., Kudryashova V.A., Lebedev V.A. O yurskom vulkanizme i vulkanakh Shadaronskoy vpadiny Yugo-Vostochnogo Zabaykalya [On the Jurassic volcanism and volcanoes of the Shadaron depression in the South-Eastern Transbaikalia]. Journal of Volcanology and Seismology, 2016, vol. 10, no. 2, pp. 86-99.

23. Abramov B.N. The Noion-Tologoi polymetallic deposit: formation conditions and petrogeochemical peculiarities of rocks and ores (Eastern Transbaikalia). Russian Geology and Geophysics, 2017, vol. 58, no. 2, pp. 177-189. In Rus.

24. Khlif N., Sasim S.A., Andreeva U.S. Elemental features and petrogenesis of the volcanic rocks of the Kailassk and Turginsk suites of the Alexandrovo-Zavodsk depression, South-East Transbaikal area. Bulletin of Irkutsk state University. Series: Earth Sciences, 2017, vol. 19, pp. 108-129. In Rus.

25. Abramov B.N., Kalinin Yu.A., Kovalev K.R., Posokhov V.F. Shirokinsky ore cluster (Eastern Transbaikalia): conditions of formation, geochemistry of rocks and ores, connection with magmatism. Bulletin of the Tomsk Polytechnic University. Geo Assets Engineering, 2017, vol. 328, no. 6, pp. 6-17. In Rus.

26. Velikoslavinskiy S.D., Krylov D.P. Geodinamicheskaya tipizatsiya magmaticheskikh porod srednego sostava po geokhimicheskim dannym [Geodynamic typification of medium composition magmatic rocks based on geochemical data]. Petrologiya, 2015, vol. 23 , no. 5, pp. 413-420.

27. Peccerillo R., Taylor S.R. Geochemistry of Eocene calk-alkaline volcanic rocks from the Kastamonu area, northern Turkey. Contributions to Mineralogy and Petrology, 1976, vol. 58, pp. 63-81.

28. Merkulova T.V., Mishin L.F. Oxidation-reduction processes in Mesozoic-Cenozoic volcano-plutonic systems and their role in the Formation of regional gravity and magnetic anomalies, the Far East. Russian Journal of Pacific Geology, 2015, vol. 34, no. 6, pp. 112-124. In Rus.

29. Mishin L.F., Romanovskiy N.P. Okislitelno-vosstanovitelnye obstanovki formirovaniya i metallogenicheskaya spetsializatsiya rudno-magmaticheskikh sistem yuga Dalnego Vostoka [Redox conditions of formation and metallogenic specialization of oremagmatic systems in the south of the Far East]. Russian Journal of Pacific Geology, 1992, no. 6, pp. 31-42.

30. Seravkin I.V., Kosarev A.M., Salikhov L.I., Znamenskiy S.E., Rodichev Z.I., Rykus M.V. Vulkanizm Yuzhnogo Urala [South Ural volcanism]. Moscow, Nauka Publ., 1990. 197 p.

Received: 22 February 2020.

\section{Information about the authors}

Bair N. Abramov, Dr. Sc., leading researcher, Institute of Natural Resources, Ecology and Cryology, SB RAS. 